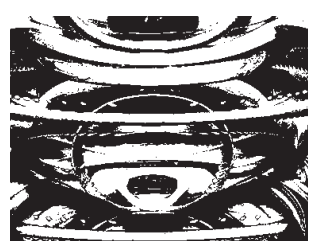

doi:10.5559/di.22.2.01

\title{
INSTITUTIONAL DEVELOPMENT AS A DETERMINANT OF FDI ATTRACTIVENESS IN SOUTHEAST EUROPE
}

Ines KERSAN-ŠKABIĆ

Juraj Dobrila University of Pula, Pula

UDK: 339.727.22(100:4-12)

Izvorni znanstveni rad

Primljeno: 4. 2. 2013.

The author is grateful to the anonymous referees for very helpful and constructive suggestions on the first draft of this paper.

The aim of this paper is to research the institutional environment in SEE countries (Albania, Bosnia and Herzegovina, Bulgaria, Croatia, Macedonia, Montenegro, Romania and Serbia) and its importance in attracting FDI inflows. Several regression models are created to determine the significance of chosen location determinants. The models include institutional variables about the transition progress, government effectiveness, rule of law, corruption, but also variables about the economic characteristics of the SEE region such as GDP per capita, growth rate, inflation and wages. The results of the panel data analysis indicated the importance of economic determinants (GDP p.c. and inflation) to FDI inflows, while among institutional factors, only corruption, large scale privatisation, the development of trade and forex systems, and overall infrastructure reform have a significant impact on FDI inflows. Property rights freedom and small scale privatisation are not significant variables. When we reduce multicollinearity, we conclude that GDP p.c., inflation, the trade and forex systems, corruption and overall infrastructure reform remain significant variables in explaining the economic and institutional determinants of FDI inflows.

Keywords: institutional development, FDI, SEE region 
In times of scarce domestic capital and investments, foreign direct investments (FDIs) are needed to push forward the domestic economy and employment. They are usually seen as a solution to boost economic growth and exports and they may help achieve modernisation, industrial upgrading and improve productivity by importing foreign technologies, diffusing knowledge and Western best practices. Developing countries often try to attract more FDI with their own economic policies and incentives, in the expectation of a positive impact on the domestic economy.

The countries of Southeast Europe (SEE) have gone through a process of transition, accompanied by liberalisation and privatisation, where foreign capital has played a very important role. Not all SEE countries have been equally successful in attracting foreign capital and their position depends on the specific location and institutional characteristics of each country. The Western Balkan states were faced with disintegration processes and a lack of mutual cooperation until the 2000s. Because of this, they have been lagging behind Central and East European (CEE) countries in terms of the amount of FDI. For example, in the period between 1993 and 2011, among the CEE countries, Estonia received EUR 10,507, Czech Republic EUR 7,418 and Hungary EUR 5,962 per inhabitant, while in the region of the SEE countries, Montenegro (EUR 6,500) and Croatia (EUR 5,787) received the largest amount of FDI per inhabitant.

The question is: what determines FDI inflows in the SEE region? This region is not as large as the CEE market (total population), so market size (population) is probably not the most influential factor where FDI inflows are concerned. The assumption is that the influential factors are the following: GDP per inhabitant, wage level, infrastructure development, as well as institutional frameworks, which may be the reason for the unsatisfactory amount of inward FDI.

There has been a lot of analysis of the attractiveness of a particular country or a group of similar countries (Markusen, 1998; Markusen \& Venables, 1998). Location determinants are a very broad concept and include traditional factors such as the availability of natural resources (prices, infrastructure), market size (living standards, wages, production costs), the macroeconomic environment (inflation, unemployment, interest rates, GDP growth rates); however, we must not forget institutional factors (property rights, FDI incentives, bilateral trade/investment agreements, taxes, etc.).

In the case of developing countries, institutional frameworks are crucial as a guarantee of market functioning (Glo- 
DRUŠ. ISTRAŽ. ZAGREB GOD. 22 (2013), BR. 2 STR. $215-235$

KERSAN-ŠKABIĆ, I.: INSTITUTIONAL... berman \& Shapiro, 2002). Institutional weaknesses, frequent changes in laws and inefficiency (slowness) of public administration, may cause a weak inflow or the absence of FDI inflows. The inclusion of institutions in relation to FDI inflows is particularly important for developing countries, because developed countries have strong institutional frameworks conducive to business development and market forces.

The reliability and safety of institutions has emerged in economic literature (North, 1991; Coase, 2002; Williamson, 2000; North, 2005), in the first place as a catalyst for growth (Edison, 2003; Rodrik, Subramanian, \& Trebbi, 2004; Rodrik, 2004) and as an inward-FDI attractor mainly in transition economies (Pournarakis \& Varsakelis, 2004; Bevan \& Estrin, 2004). ${ }^{1}$ A nation's institutional environment is the set of political, economic, social and legal conventions that establish the foundational basis for production and exchange (Oxley, 1999; Sobel, 2002). New institutional economics extends economics with social and legal norms that influence market functioning in the neoclassical framework. The idea is to include the efficiency of institutions in the analysis of market economies. It includes a variety of indicators such as: property rights, governance efficiency, social norms and social capital, human assets, asymmetric information, strategic behaviour, opportunism, moral hazard, contractual safeguards, monitoring costs, incentives to collude, hierarchical structures, etc. Institutions, i.e. legal, politi$\mathrm{cal}$ and administrative systems tend to be internationally immobile frameworks whose costs determine the international attractiveness of a location. Institutions may not be only considered as preconditions for FDI, they have also been built in the process of transition because there is interaction between foreign investors and institutions in the host countries. Problems occur in defining the coverage of institutions and in measuring institutional development. ${ }^{2}$

The goal of this paper is to find out the role of institutions in attracting FDI inflows in the SEE region and to determine the relation between institutional factors and levels of FDI. The paper is organized into 4 chapters. The following chapter is a review of the literature, the third chapter focuses on research (methodology and results), and the fourth is the conclusion.

\section{LITERATURE REVIEW}

\section{Determinants of FDI}

There are many determinants that influence a country's ability to attract foreign capital depending on the level of development of a particular country. In the case of developing countries, the most important factors are market size, production 
DRUŠ. ISTRAŽ. ZAGREB GOD. 22 (2013), BR. 2, STR. $215-235$

KERSAN-ŠKABIĆ, I. INSTITUTIONAL... costs, availability of production factors, and institutional framework regarding market functioning i.e. property rights, administration, establishment of new commercial enterprises, stimulation measures etc. During the 1990s, privatisation was a strong factor in receiving foreign capital (Bevan \& Estrin, 2004). The significance of institutional factors is lower when we observe and analyse FDI flows among developed countries, because these countries already have institutional frameworks which are "invisible" in their long-term market oriented economies.

Dunning (1992) introduced an eclectic paradigm, known as the OLI paradigm, with three important elements needed in order to motivate investment in a particular country: ownership, location and internalisation advantages. Dunning's location advantages include: supply side (labour skills and costs, corporate taxation), demand side (market size and growth), and political and social infrastructure. Since Dunning's initial paradigm did not specifically include institutional factors, being principally focused on economic factors, Dunning (2006) emphasized the importance of institutional factors in an extension of the model. It has also been suggested that institutions affect all three components of the paradigm (Dunning \& Lundan, 2008).

The focus in this paper will be on those determinants of FDI which influence the investor's decision as to where to invest. Although institutional factors are important for building the confidence of foreign investors, the analysis of other factors (market size, GDP growth rates, labour costs, etc.) prevail in research relating to localization determinants. Growth rates are an important localization factor, so the fastest growing countries are also the biggest FDI-host countries (Balasubramanyam, Salisu, \& Sapsford, 1996; Borensztein, De Gregorio, \& Lee, 1998; De Mello, 1999; Merlevede, 2000; Zhang, 2001). Frey and Schneider (1985) find that the determinants of FDI inflows in less developed countries may be best explained by a combination of political and economic variables.

What should be analysed in the functioning of institutions? Only formal institutions and administrative actions, or should we include informal elements which influence behaviour and non-commercial operating results (Schmieding, 1993)? Grogan and Moers (2001) consider institutions in terms of property rights, the effective application of laws and regulations, and the degree of corruption. It is difficult to approach institutions in a wholly right way, and to incorporate all that the word 'institution' encompasses.

The recent situation in the SEE region has highlighted the importance of an enabling institutional environment in reaping the maximum benefits from FDI inflows. In the last decades there have been various analyses of the importance of in- 
DRUŠ. ISTRAŽ. ZAGREB GOD. 22 (2013), BR. 2, STR. $215-235$

KERSAN-ŠKABIĆ, I.: INSTITUTIONAL... stitutions with regard to their efficiency and power to attract foreign capital (Acemoglu \& Johnson, 2005; IMF, 2003). Daude and Stein (2007) find that poor institutions can act as a tax burden, and therefore as a cost, to FDI. Aizenman and Spiegel (2006) find that institutional efficiency is strongly correlated with the ratio of FDI to total domestic investment. Rodrik et al. (2004) distinguish four types of institution: market creating institutions that protect property rights and make contracts fair and reliable; market regulating institutions that help regulate market externalities, imperfect and asymmetric information or economic scales in sectors like transportation, telecommunication or environment; market stabilising institutions that reduce macroeconomic instabilities and prevent major crises; and market legitimising institutions which support social protection and manage social conflict. Kogut and Spicer (2002), and Stiglitz (1999) think that the establishment of new institutions is at least as important as more conventional macroeconomic policy objectives. Kaufmann, Kraay, and Mastruzzi (2004) include: political stability, government effectiveness, regulatory quality, rule of law, and control of corruption. La Porta, Lopez-de-Silanes, Shleifer, and Vishny (1999) include a property rights index, a business regulation index, corruption, and bureaucratic delays. Based on a large sample of 73 developed and developing countries, Egger and Winner (2005) found a positive relationship between corruption and FDI.

Bénassy-Quéré, Coupet, and Mayer (2007) investigated the quality of institutions (bureaucracy, corruption, information, a banking sector, and legal institutions) in home and host countries, and found that institutional distance tends to reduce bilateral FDI flows. Brunetti, Kisunko, and Weder (1997) connected the differences in the degree of predictability of FDI inflows related to institutional framework in transition countries. The significant degree of differences in FDI across the range of transition economies could be explained by expectations of unstable or stable institutional frameworks. Buchanan, Le, and Rishi (2012) made a panel data analysis of 164 countries from 1996 to 2006, and examined the impact of institutional quality on FDI levels and volatility. They found that good institutional quality has a positive and significant effect on FDI.

\section{FDI in the SEE Region}

Although the countries in the region share some common features (corruption, non-application of the rule of law, slow administration, adverse business environment), there are some differences between them in terms of success and their attractiveness to foreign investors. Croatia is the most developed country in the region, with GDP per capita of EUR 10,400 (which 
DRUŠ. ISTRAŽ. ZAGREB GOD. 22 (2013), BR. 2, STR. 215-235

KERSAN-ŠKABIĆ, I.: INSTITUTIONAL... is $61 \%$ of the EU-27 average), followed by Romania and Bulgaria, and Albania and Bosnia and Herzegovina are at the bottom of the list (30\% of the EU-27 average). In terms of FDI inflows in absolute values, Romania and Bulgaria as the biggest countries of the region occupy top positions, but in terms of relative values Montenegro and Croatia attract the highest inflow per capita. It is interesting that Croatia had the highest FDI stock per capita until 2010, when Montenegro took over this position. These numbers were the result of the policy of opening the Montenegrin economy to foreign investment, as well as of incentive policies (mostly in terms of tax reliefs Montenegro has the lowest profit tax rate of only 9\%). Albania, Bosnia and Herzegovina and Macedonia have attracted the least FDI per capita because of: corruption, geopolitical risk, lack of modern infrastructure, the lack of commitment to true reforms (Vaknin, 2011). It should be pointed out that Serbia has managed to attract the biggest number of greenfield projects (over 100 in 2008 and 2011). At the same time, Croatia has attracted 50-odd such projects, with the largest share of FDI in the services sector (banking, telecommunications, tourism) (WIIW, 2012). It is also interesting to point out the difference in tax rates on profits - Croatia has the highest rate, which is twice as high as the rate in most SEE countries (where most have a rate of $10 \%$ ).

The SEE countries, separately, are usually not the subject of analysis in terms of FDI determinants. Demekas, Horvath, Ribakova, and $\mathrm{Wu}(2007)$ researched the location factors of host economies in the countries of Central, Eastern and Southern Europe, and in the Baltic States. They found no explanatory factors specific to Southeast Europe at work, while for other countries the results are in line with expectations: high unit labour costs, a high corporate tax burden, and, to a lesser extent, high import tariffs, discourage non-privatisation-related FDI, while a liberal foreign exchange and trade regime, and advanced reforms in the infrastructure sector, encourage it. Zeghni and Fabry (2006) investigated the role of institutions in attracting FDI inflows in 11 post-communist European economies (including, among others, Croatia, Romania and Bulgaria). The results confirm their expectations that FDI is sensitive to specific and local institutional arrangements.

In this analysis we deal with the aggregate data of FDI inflows and do not include bilateral FDI flows (as Bevan \& Estrin, 2004), because EU member states are the main investors in the SEE region (for example, in Croatia about $90 \%$ of total FDI inflows come from the EU). These countries have good governance infrastructure; however, the level of institutional development of the SEE countries is also important. 
DRUŠ. ISTRAŽ. ZAGREB GOD. 22 (2013), BR. 2 STR. $215-235$

KERSAN-ŠKABIĆ, I.: INSTITUTIONAL...
The contribution of this paper is the following: analysis is carried out on a group of SEE countries not usually observed separately; in previous researches they are grouped together under the heading of developing countries or countries in transition. Moreover, previous researches do not include all countries of the SEE region, because they started to be active in the international community relatively recently (late 1990s). The problem arises with regard to statistical data for these countries, as well as data about levels of institutional development. The data have been available for only a short period (and some data are still missing), and these are the limitations to the method used in this research. There is no previous research on the institutional determinants of FDI inflows in the SEE region.

\section{RESEARCH}

\section{Data and sources}

In total, the final sample includes data from eight countries in Southeast Europe in the period 2001-2010. The summary statistics and correlation matrix for the variables are provided in the Appendix. A large number of potential determinants of FDI has been analysed in the literature. However, our focus is specific to the role of institutions. The control variables are GDP per capita, wages and inflation. GDP per capita is a measure of a country's purchasing power and is expected to have a positive effect on FDI. This variable is important for market-seeking FDI, which is replacing export driven FDI, and is oriented toward supplying domestic markets. Wages reflect the cost of labour and also, indirectly, productivity differences among the countries. Low wages are also an important location determinant, because they can influence the reduction of production costs and increase profitability. Finally, inflation is meant to measure instability at the macro level, which seems to be unfavourable for capital accumulation and economic growth, as it degrades the business climate. Adverse economic conditions do not only discourage foreign interest, but also reduce the productivity effect (Prüfer \& Tondl, 2008).

In order to take into account the role of institutions, we rely on three main sources, namely: the EBRD transition indicators, Economic Freedom data (The Heritage Foundation), and Transparency International. We are mainly concerned with variables which can affect the decision of MNCs to invest in a country. These include an effective system of property rights, infrastructure reform, and non-corrupt public officials (since corruption might significantly delay the start of business operations and result in a withdrawal from investments, both fo- 
DRUŠ. ISTRAŽ. ZAGREB GOD. 22 (2013), BR. 2, STR. $215-235$

KERSAN-ŠKABIĆ, I.: INSTITUTIONAL... reign and domestic). Government policies encouraging a free and open market are also an important FDI determinant.

The European Bank for Reconstruction and Development publishes the Transition Report, in which it processes many indicators to assess improvements in large scale privatisation, small scale privatisation, trade liberalisation, price liberalisation, competition policy, restructuring economies, and overall infrastructure reform (roads, railways, telecommunication, water supply etc.). The scores are from 1 to $4+$, and are based on an assessment of the size of challenges in terms of two components: market structure and market-supporting institutions and policies. They measure the transition gap (deviation from efficient market structure). Score 1 to 2 means that there is a large transition gap, and score 4 or $4+$ means that this gap is negligible. The ratings of overall infrastructure reform are calculated as the average of five infrastructure reform indicators covering electric power, railways, roads, telecommunications, water and waste water. The influence of the EBRD indicators on FDI inflows is positive (EBRD, 2012).

The Wall Street Journal and The Heritage Foundation publish the Index of Economic Freedom which covers 10 freedoms grouped into four broad categories: rule of law (property freedom, freedom from corruption), limited government (fiscal freedom, government spending), regulatory efficiency (business freedom, labour freedom, monetary freedom) and open markets (trade freedom, market freedom, financial freedom). Each of these freedoms is scored on a scale of 1 to 100 , where 100 represents the maximum freedom.

Transparency International measures levels of corruption in the public sector, and assesses the Corruption Perception Index (CPI), starting from 1995. It is a composite index, a combination of polls, drawing on corruption-related data collected by a variety of reputable institutions. A scale of $0-10$ is applied to measure the perception of corruption, where 0 means that a country is perceived as highly corrupt and 10 means that a country is perceived as not corrupt. The expected impact of the CPI on FDI inflows is positive (a higher score means less corruption).

A common problem of institutional variables is their measurement. Since most data are collected from surveys, they might reflect the subjective views of managers and other stakeholders. Apart from the above-mentioned sources, there are other sources used in the literature, such as the Worldwide Governance Index, the World Bank Doing Business Index, and the Global Competitiveness Index from the World Economic Forum (institutions are one of the 12 pillars of competitiveness). These will not be discussed here because they will not be used in further analysis due to differences in methodology and scope, as well as the overlapping of similar institutional variables. 
DRUŠ. ISTRAŽ. ZAGREB GOD. 22 (2013), BR. 2 STR. $215-235$

KERSAN-ŠKABIĆ, I.: INSTITUTIONAL...
From this short review, it is clear that there are different approaches to measuring institutional development, as well as different methodologies. These are the limitations to the inclusion of institutional variables of different organisations, and point to the invalidity of their comparison. Some institutions show a country's success score (points), others produce only ranks, and the number of countries under analysis varies from year to year. Because of this, in the group of institutional variables, the model will include: EBRD transition indicators (enterprise restructuring, large scale privatisation, small scale privatisation, trade and forex systems, overall infrastructure reform), property rights freedom from the Heritage Foundation, and the corruption perception index from Transparency International. The data set covers the period 2001-2010.

\section{Methodology and model}

Considering that the sample has a cross-sectional dimension, represented by countries $(i=1 ;::: ; N)$ and a longitudinal dimension, represented by a time series $(t=1 ;::: ;$ T periods $)$, the panel data method will be used (Hsiao, 2003). The SEE countries are: Albania, Bosnia and Herzegovina, Bulgaria, Croatia, Macedonia, Montenegro, Romania and Serbia. The sample comprises unbalanced panel data, i.e. there are some time periods missing from some units in the population of interest.

We used random effects (RE) and fixed effects (FE) estimation methods, which allow us to deal with the problem of unobserved heterogeneity. While the FE models capture country-specific effects with $\alpha i$, which do not change over time, the RE method incorporates heterogeneity among the countries by including a specific unobservable effect ( $\varepsilon i t)$ in the error term. All models are tested using the Hausman test to decide between RE and FE and standard errors that are robust to heteroscedasticity and autocorrelation. The Hausman test fails to reject the null hypothesis that the difference in coefficients is not systematic, thus favouring random effects in several models. However, the Lagrange multiplier test favours pooled OLS over random effect, while the F test indicates that there is a correlation between unobserved fixed effects and independent variables. Furthermore, we are not interested in making broader inferences from our findings beyond the group we have as the sample, thus the use of fixed effects is most certainly warranted. Moreover, the institutional variables are specific to this group of countries since the progress in terms of reforms is not uniform.

We model several specifications in order to deal with multicollinearity among the institutional variables. This approach is widely followed in the literature (e.g. Walsh \& Yu, 2010; Chakrabarti, 2001). The correlation matrix shows that, in general, 
DRUŠ. ISTRAŽ. ZAGREB GOD. 22 (2013), BR. 2, STR. 215-235

KERSAN-ŠKABIĆ, I. INSTITUTIONAL... multicollinearity is not a serious problem. The highest correlation is observed between GDP per capita and corruption $(0,70)$. However, interpretation should be made cautiously since some institutional variables included in the model may also capture the effects of omitted institutions. Therefore, in the last three models we simultaneously included several institutional variables to deal with the omitted variable bias. The dependent variable and control variables (GDP per capita, inflation, wages, growth rate) were logged to interpret the coefficient as elasticities. Furthermore, taking logs enabled us to scale down the variation in data and generate better results in terms of statistical significance and standard errors. ${ }^{3}$ The institutional variables are constructed as indices and therefore are not logged. All models are corrected for autocorrelation and heteroscedasticity by using cluster robust standard errors.

A common problem when trying to identify the effects of institutions on economic outcomes is that countries are not exogenously endowed with institutions that promote good governance (Buchanan et al., 2012). It is reasonable to assume that FDI is not only influenced by institutional frameworks, because once MNCs are located in the host country, they may demand better institutions, thus creating the reverse causality problem. For example, survey respondents may perceive the host country's institutional framework as weak because they observe very low levels of FDI. This again leads to the reverse causality problem, since it is not only institutions that affect economic performance, but also economic variables affect the perceived institutions of a country. One way to deal with the simultaneity bias is to use the GMM estimator. However, the latter is designed for large $\mathrm{N}$ and small $\mathrm{T}$ as cluster robust standard errors and the autocorrelation tests are unreliable (Roodman, 2009). Furthermore, estimates are biased and imprecise and serial correlation is not an issue according to the Wooldridge test. Therefore, the use of the static panel model is justified. Another approach is to use instrumental variable regression. However, it is very difficult to find good instruments as the quality of institutions is probably determined by more fundamental and historical reasons. Given that we have a very small sample of countries that have undergone the transformation process from centrally planned to market-oriented economies, and are a relatively homogenous group in terms of legal origin, we decided to use one-period lagged values of institutional variables in FE regressions to partially control for simultaneity bias which might occur given the fact that quality of institutions affect FDI and vice versa. ${ }^{4}$ Furthermore, lags of institutional variables enable us to capture time lag between their development and their influence on FDI. Finally, empirical tests suggest that simultaneity is not a problem in our regressions, thus confirming our decision to use FE (Appendix). ${ }^{5}$ 
DRUŠ. ISTRAŽ. ZAGREB GOD. 22 (2013), BR. 2 STR. 215-235

KERSAN-ŠKABIĆ, I.: INSTITUTIONAL...
The relationship between FDI inflows and their determinants is as follows:

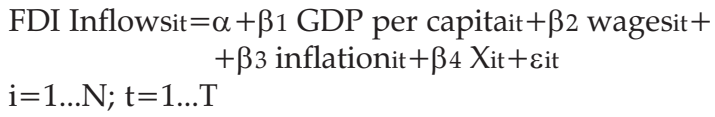

where the dependent variable is FDI inflows and the independent variables are: GDP per capita, inflation, wages, growth rate and institutional variables: enterprise restructuring, large scale privatisation, small scale privatisation, corruption perception index, property rights freedom, trade and forex systems. FDI inflows are taken as the dependent variable because these countries have very low FDI outflows, and the goal is to determine the impact of the independent variables on their FDI attractiveness and the dynamics of inflows (rather than FDI stock). ${ }^{6}$ The data are taken from WIIW (2012).

The first model includes the economic location determinants of a particular market: GDP per capita, inflation, growth rate and wages. GDP per capita is used as a proxy for purchasing power in the host country, inflation as a proxy for price stability, and wages reflect the labour costs to which the efficiency type of FDI is very sensitive. Only GDP per capita is significant and it has the expected sign. Model 2 includes enterprise restructuring and model 3 includes reforms in trade and exchange rate policies, but neither variable is significant. According to model 4, GDP per capita has the expected sign, but is no longer significant, while corruption perception and inflation are. The sign of inflation is contrary to expectations, suggesting that macroeconomic instability leads to more FDI inflows. The magnitude of corruption suggests that a one standard deviation increase in this dimension would increase FDI by a factor of $2.07(\exp 0.731)$.

The property right index is included in model 5 and it has a positive influence on FDI inflow, although not significant. Privatisation in the transition countries was the main channel of foreign capital inflows in the initial stage of the liberalisation of financial flows and we expected a positive impact of privatisation on FDI inflows. Model 6 shows a positive and a significant influence of large scale privatisation, while small scale privatisation does not have a significant influence on FDI inflow. Model 7 incorporates enterprise restructuring and corruption as the main institutional variables. Again, corruption has a statistically positive sign, as do wages and inflation, while GDP per capita loses its significance. Models 8 and 9 try to incorporate more institutional variables, but in these cases only trade and forex reform and corruption have a significant influence on FDI inflows among other institutional variables.

The results are partly in accordance with the results of Zeghni and Fabry (2006), but also differ in the last two models where they show a significant simultaneous effect of various 
(1) TABLE 1

Determinants of FDI

inflows in SEE

countries (FDI inflows

dependent variable) institutional variables on FDI trends. But there are limitations to the comparisons: they consider only three countries in the SEE region (Romania, Bulgaria and Croatia) and use data from the period 1992-2003, during which period institutional structures changed significantly, and therefore institutional indicators had greater significance.

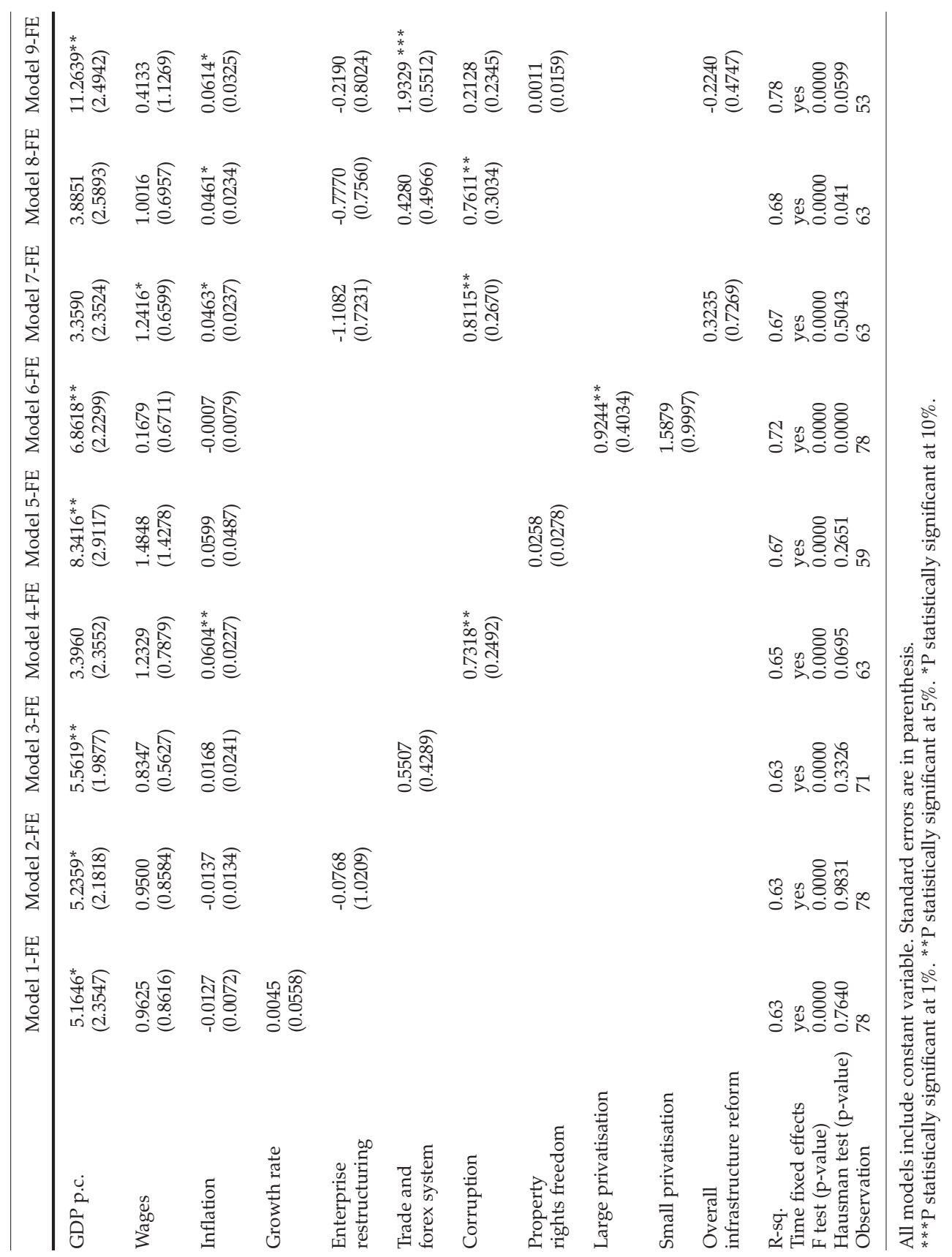


DRUŠ. ISTRAŽ. ZAGREB GOD. 22 (2013), BR. 2 STR. 215-235

KERSAN-ŠKABIĆ, I.: INSTITUTIONAL...

(1) TABLE 2

Determinants of FDI inflows in the SEE countries (nonlinearity)
The findings suggest that corruption, GDP per capita, and inflation play an important role as determinants of FDI. The fact that GDP per capita loses its significance when corruption is included might be a sign of multicollinearity. The relatively high correlations between these variables could actually preclude the identification of the partial effects of GDP per capita of a country and of its institutions.

One solution to reduce multicollinearity is to drop the variable, but by doing so one would make a specification error if the true coefficient of variable that is dropped is different from zero. Therefore, we decided to examine how corruption and GDP per capita interact. By introducing nonlinearity into the model, we are able to gain some insight into the impact of GDP per capita at different levels of corruption.

\begin{tabular}{|c|c|c|c|c|}
\hline & Model $10-$ FE & Model $11-$ FE & Model $12-$ FE & Model $13-$ FE \\
\hline GDP p.c. & $\begin{array}{l}7.3648^{* * *} \\
(2.1684)\end{array}$ & $\begin{array}{l}6.4986^{* *} \\
(2.1497)\end{array}$ & $\begin{array}{l}6.3738^{* *} \\
(2.5113)\end{array}$ & $\begin{array}{l}13.8391^{* * *} \\
(1.9130)\end{array}$ \\
\hline Wages & $\begin{array}{l}-0.5455 \\
(1.2158)\end{array}$ & $\begin{array}{l}1.0947^{*} \\
(0.5289)\end{array}$ & $\begin{array}{l}0.9936 \\
(0.6150)\end{array}$ & $\begin{array}{l}0.3946 \\
(0.5428)\end{array}$ \\
\hline Inflation & $\begin{array}{l}0.0319 \\
(0.040)\end{array}$ & $\begin{array}{l}0.0452^{*} \\
(0.0216)\end{array}$ & $\begin{array}{l}0.0454^{*} \\
(0.0220)\end{array}$ & $\begin{array}{l}0.0624^{* *} \\
(0.0225)\end{array}$ \\
\hline Enterprise restructuring & & $\begin{array}{l}-1.3432^{* *} \\
(0.5472)\end{array}$ & $\begin{array}{l}-1.1574 \\
(0.7735)\end{array}$ & $\begin{array}{l}-0.4572 \\
(0.6116)\end{array}$ \\
\hline Trade and forex system & & & $\begin{array}{l}0.2431 \\
(0.5339)\end{array}$ & $\begin{array}{l}1.8625^{* * *} \\
(0.4843)\end{array}$ \\
\hline Corruption & $\begin{array}{l}11.9549^{* *} \\
(4.0774)\end{array}$ & $\begin{array}{l}9.3672^{* * *} \\
(2.6730)\end{array}$ & $\begin{array}{l}8.3996^{* *} \\
(3.2083)\end{array}$ & $\begin{array}{l}7.5008^{* * *} \\
(1.5373)\end{array}$ \\
\hline Property rights freedom & & & & $\begin{array}{l}0.0015 \\
(0.0157)\end{array}$ \\
\hline GDP p.c. ${ }^{*}$ corruption & $\begin{array}{l}-1.3565^{* *} \\
(0.4475)\end{array}$ & $\begin{array}{l}-0.9477^{* *} \\
(0.2872)\end{array}$ & $\begin{array}{l}-0.8517^{* *} \\
(0.3425)\end{array}$ & $\begin{array}{l}-0.8011^{* * *} \\
(0.1798)\end{array}$ \\
\hline \multicolumn{5}{|l|}{ Large privatisation } \\
\hline \multicolumn{5}{|l|}{ Small privatisation } \\
\hline Overall infrastructure reform & & $\begin{array}{l}-0.2112 \\
(0.6899)\end{array}$ & & $\begin{array}{l}-0.8303^{* *} \\
(0.3176)\end{array}$ \\
\hline R-sq. & 0.32 & 0.70 & 0.70 & 0.80 \\
\hline Time fixed effects & yes & yes & yes & yes \\
\hline F test (p-value) & 0.0000 & 0.0000 & 0.0000 & 0.0000 \\
\hline Hausman test (p-value) & 0.0938 & 0.9189 & 0.5574 & 0.0520 \\
\hline Observation & 63 & 63 & 63 & 53 \\
\hline
\end{tabular}


DRUŠ. ISTRAŽ. ZAGREB GOD. 22 (2013), BR. 2, STR. 215-235

KERSAN-ŠKABIĆ, I. INSTITUTIONAL...

\section{CONCLUSION}

GDP per capita remains highly significant in explaining FDI in the selected countries. The results suggest that a $1 \%$ increase in GDP per capita leads to an increase in FDI from 6.37\% to $13.83 \%$. The corruption perception index still remains significant as well as the interaction term. The point index of corruption implies that an increase by one point in this variable leads to an 11 percent increase in FDI in model 10. The interaction term indicates that in the countries with higher corruption the effect of GDP per capita on FDI is less relevant. In model 11, enterprise restructuring becomes significant and indicates that progress in restructuring keeps MNCs away from a host country due to the competition effect. In model 12, we repeated the specification from model 8 and augmented it with the interaction term. However, it seems that trade and forex reform has little influence on FDI, while GDP per capita, corruption and the interaction term play an important role as FDI determinants. Finally, in model 13, we incorporated all institutional variables to account for possible omitted variable bias. It seems that a combination of institutions provide the best results in attracting FDI. This provides policy makers with some interesting implications. It seems that foreign investors are not attracted only by low levels of corruption, but also by other institutional variables, such as trade and forex reform, as well as infrastructure reform which seems to negatively affect FDI inflows.

Institutional development is an important determinant in attracting foreign investment to developing countries, particularly to countries in transition. The SEE region can be attractive to foreign investors because of its location advantages: GDP per capita, abundance of resources, but also because of the safety of investments (meaning a good regulatory framework and institutional efficiency).

The indicators of institutional development (EBRD, World Bank, Heritage Foundation) point out many weaknesses in the SEE region: a relatively high perception of corruption, the poor development of institutions in terms of competitiveness, poor credit ratings, inefficient government, rule of law, political stability.

The regression results pointed to the importance of economic determinants in FDI inflows (GDP p.c. and inflation), while among institutional factors only corruption, large scale privatisation, the development of trade and forex systems, and overall infrastructure reform have a significant impact. Surprisingly, property rights freedom is not as significant a va- 
DRUŠ. ISTRAŽ. ZAGREB GOD. 22 (2013), BR. 2 STR. $215-235$

KERSAN-ŠKABIĆ, I.: INSTITUTIONAL... riable as small scale privatisation. The limitation of the model is that it could not include more variables because of data availability or because of the correlation with the observed variables. When we reduce multicollinearity, it can be seen that GDP p.c., inflation, trade and forex system, corruption and overall infrastructure reform remain significant variables in explaining the economic and institutional determinants of FDI inflows. The influence of institutional variables changed as we extended the model with additional institutional variables; moreover, their impact on FDI inflows is relatively low (in comparison with GDP p.c.).

A greater influence of institutional indicators on FDI inflows was expected, but the economic determinants were dominant with their force and significance, thus institutions turned out not to be crucial for foreign investors. However, it should be noted that all the countries have recorded significant improvements in institutional infrastructure in the last 10 years, which is why the importance of institutions is lower since they are perceived as effective in advance. The structure of FDI, which is largely focused on the services sector, indicates that foreign investments come to supply the domestic market, which favours the notion that economic determinants attract FDI.

\section{NOTES}

${ }^{1}$ North (1991) indicates two types of institutional constraints: formal rules (constitution, laws, property rights) and informal restraints (sanctions, taboos, customs, traditions, codes of conduct), which usually contribute to the perpetuation of order and safety within a market or society. In his paper from 2005, he points out that economic performance is determined by the kind and quality of institutions that support markets. Coase (2002) stresses the need to include the functioning of institutions (legal, political, social and educational systems, culture, etc.) which create the environment where people live (work, earn and spend their income) and companies operate (and it greatly affects their cost and performance) in the analytical framework of analysis in economics.

2 Williamson highlights four levels of institutions: L1-social theory; L2-economics of property rights (positive political theory); L3-transaction cost economics; L4-neoclassical economics (agency theory). The first level includes: norms, customs, traditions, religion, and given that these elements change slowly over time, the level of these institutions is often taken as a given and economists do not monitor the impact of its changes. The second level is the institutional environment and it refers to formal institutional aspects: the executive, legislative, and judicial functions of bureaucratic government and the degree of decentralisation (federalism). In respect of attracting FDI, the protection of property rights is significant, as is the rule of law. The fourth level refers to the adaptation of ex-ante companies to 
DRUŠ. ISTRAŽ. ZAGREB GOD. 22 (2013), BR. 2, STR. 215-235

KERSAN-ŠKABIĆ, I.: INSTITUTIONAL.. prices and market conditions. Economists usually research the second and the third institutional levels in analysis.

3 A common problem when the dependent variable is logged is how to deal with observations with zero values. However, all countries in our dataset contain data on FDI.

${ }^{4}$ We tried to use several external instruments (ethno linguistic fractionalisation and a dummy variable indicating that a country was a part of Yugoslavia), but both instruments failed to pass proper identification tests.

5 The Durbin-Wu-Hausman endogeneity test was performed and the results imply that there is no endogeneity in the models (Appendix - Table 5).

${ }^{6}$ For example, in 2011 net FDI was EUR 7,657 and FDI inflows EUR 8,018 . There is a small difference between FDI inflows and net FDI in the SEE region.

\section{APPENDIX}

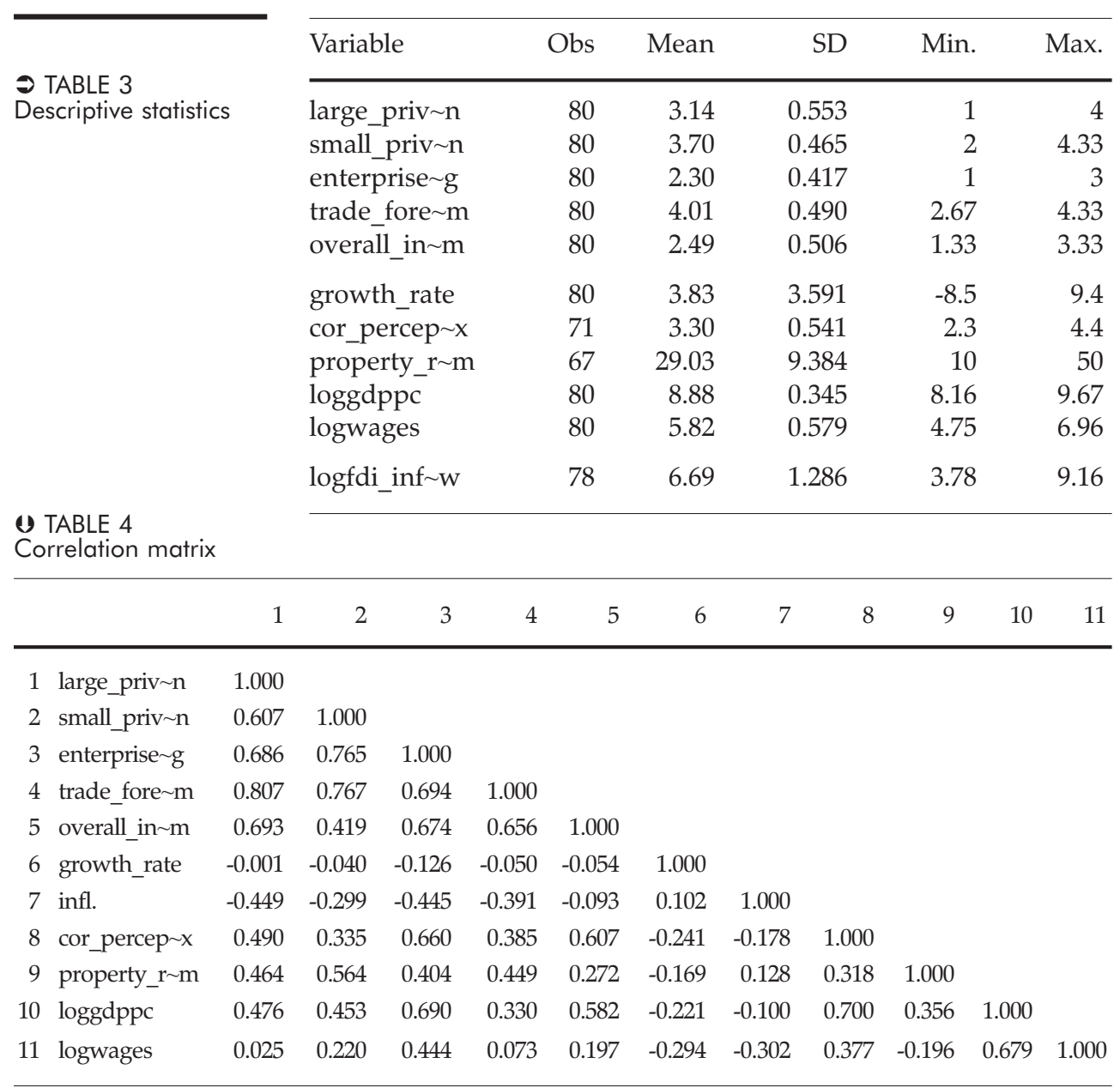


O TABLE 5

Durbin-Wu-Hausman test for endogeneity (of endogenous regressors)

\begin{tabular}{llr}
\hline Variable & & $\begin{array}{r}\text { DWH test } \\
\text { P values }\end{array}$ \\
\hline Enterprise restructuring & Chi-sq(1) P-val & 1.726 \\
& & 0.189 \\
Trade and forex system & Chi-sq(1) P-val & 1.002 \\
& & 0.317 \\
Corruption perception index & Chi-sq(1) P-val & 2.608 \\
& & 0.106 \\
Property rights index & Chi-sq(1) P-val & 1.871 \\
& & 0.171 \\
Corruption perception index, overall & 5.386 \\
infrastructure reform, enterprise restructuring & Chi-sq(1) P-val & 0.146 \\
Corruption perception index, trade and forex & & 2.136 \\
system, enterprise restructuring & Chi-sq(1) P-val & 0.545 \\
Corruption perception index, overall infra- & & \\
structure reform, enterprise restructuring, & & 3.238 \\
trade and forex system, property rights index & Chi-sq(1) P-val & 0.663
\end{tabular}

\section{REFERENCES}

Acemoglu, D., \& Johnson, S. (2005). Unbundling institutions. Journal of Political Economy, 113(5), 949-995. http://dx.doi.org/10.1086/432166

Aizenman, J., \& Spiegel, M. (2006). Institutional efficiency, monitoring costs and the investment share of foreign direct investment. Review of International Economics, 14(4), 683-697. http://dx.doi.org/10.

Balasubramanyam, V. N., Salisu, M., \& Sapsford, D. (1996). Foreign direct investment and growth in EP and IS countries. The Economic Journal, 106(434), 92-105. http://dx.doi.org/10.2307/2234933

Bénassy-Quéré, A., Coupet, M., \& Mayer, T. (2007). Institutional determinants of foreign direct investment. The World Economy, 30(5), 764-782. http://dx.doi.org/10.1111/j.1467-9701.2007.01022.x

Bevan, A., \& Estrin, S. (2004). The determinants of foreign direct investment into European transition economies. Journal of Comparative Economics, 32(4), 775-787. http://dx.doi.org/10.1016/j.jce.2004.08.006

Borensztein, E., De Gregorio, J., \& Lee, J.-W. (1998). How does foreign direct investments affect economic growth? Journal of International Economic, 45(1), 115-135. http://dx.doi.org/10.1016/S0022-1996(97)00033-0

Brunetti, A., Kisunko, G., \& Weder, B. (1997). Institutions in transition: Reliability of rules and economic performance in former socialist countries. Policy Research Working Paper, 1809. Available at http:// www-wds.worldbank.org/servlet/WDSContentServer/WDSP/IB/ 2000/02/24/000009265_3971104185021/Rendered/PDF/multi_page.pdf Buchanan, B. G., Le, Q. V., \& Rishi, M. (2012). Foreign direct investment and institutional quality: Some empirical evidence. International Review of Financial Analysis, 21, 81-89. http://dx.doi.org/10.1016/j.irfa.2011.10.001 1111/j.1467-9396.2006.00595.x 
DRUŠ. ISTRAŽ. ZAGREB GOD. 22 (2013), BR. 2, STR. 215-235

KERSAN-ŠKABIĆ, I.: INSTITUTIONAL...
Chakrabarti, A. (2001). The determinants of foreign direct investment: Sensitivity analysis of cross-country regressions. KYKLOS, 54(1), 89-114. http://dx.doi.org/10.1111/1467-6435.00142

Coase, R. (2002). The new institutional economics. In The Economics of Contracts. Cambridge: Cambridge University Press, (1st edition, 45-48), http://dx.doi.org/10.1017/CBO9780511613807.002

Daude, C., \& Stein, E. (2007). The quality of institutions and foreign direct investment. Economics \& Politics, 19(3), 317-344. http://dx.doi. org/10.1111/j.1468-0343.2007.00318.x

De Mello, J. (1999). Foreign direct investment-led growth: Evidence from time series and panel data. Oxford Economic Papers, 51(1), 133-151. http://dx.doi.org/10.1093/oep/51.1.133

Demekas, D. G., Horvath, B., Ribakova, E., \& Wu, Y. (2007). Foreign direct investment in European transition economies - The role of policies. Journal of Comparative Economics, 35(2), 369-386. http://dx.doi. org/10.1016/j.jce.2007.03.005

Dunning, J. (1992). Trade, location and economic activity and the multinational enterprise: A search for an eclectic approach. In J. Dunning (Ed.), The theory of transnational corporation. The United Nations library on transnational corporation - the theory of transnational corporation (vol. 1, pp. 183-218). New York: Routledge.

Dunning, J. H. (2006). Comments on Dragon multinationals: New players in 21st century globalization. Asian Pacific Journal of Management, 23(2), 139-141. http://dx.doi.org/10.1007/s10490-006-7161-1

Dunning, J. H., \& Lundan, S. (2008). Institutions and the OLI paradigm of the multinational enterprise. Asia Pacific Journal of Management, 25(4), 573-593. http://dx.doi.org/10.1007/s10490-007-9074-z

EBRD (2012). Transition Report. Available at: http://www.ebrd.com/ pages/research/publications/flagships/transitions.html

Edison, H. (2003). Testing the links. Finance and Development, 40(2), 35-37. Available at: http://www.imf.org

Egger, P., \& Winner, H. (2005). Evidence on corruption as an incentive for foreign direct investment. European Journal of Political Economy. 21(4), 932-952. http://dx.doi.org/10.1016/j.ejpoleco.2005.01.002

Frey, B. S., \& Schneider, F. G. (1985). Economic and political determinants of foreign direct investment. World Development, 13(2), 161-175. http://dx.doi.org/10.1016/0305-750X(85)90002-6

Globerman, S., \& Shapiro, D. (2002). Global foreign direct investment flows: The role of governance infrastructure. World Development, 30(11), 1899-1919. http://dx.doi.org/10.1016/S0305-750X(02)00110-9

Grogan, L., \& Moers, L. (2001). Growth empirics with institutional measures for transition countries. Economic System, 25(4), 323-344. http:// dx.doi.org/10.1016/S0939-3625(01)00030-9

Hsiao, C. (2003). Analysis of panel data. Cambridge: Cambridge University Press, 2nd edition. http://dx.doi.org/10.1017/CBO9780511754203 IMF (2003). World Economic Outlook: Growth and Institutions. Available at http://www.imf.org

Kaufmann, D., Kraay, A., \& Mastruzzi, M. (2004). Governance matters: Governance indicators for 1996-2002. World Bank Policy Research 
DRUŠ. ISTRAŽ. ZAGREB GOD. 22 (2013), BR. 2 STR. 215-235

KERSAN-ŠKABIĆ, I.: INSTITUTIONAL...
Working Paper, 3106. Available at http://papers.ssrn.com/sol3/papers. cfm?abstract_id $=405841$

Kogut, B., \& Spicer, A. (2002). Capital market development and mass privatization are logical contradictions: Lessons from Russia and the Czech Republic. Industrial and Corporate Change, 11(1), 1-37. http://dx. doi.org/10.1093/icc/11.1.1

La Porta, R., Lopez-de-Silanes, F., Shleifer, A., \& Vishny, R. (1999). The quality of government. Journal of Law, Economics and Organization, 15(1), 222-279. http://dx.doi.org/10.1093/jleo/15.1.222

Markusen, J. R. (1998). Multinational firms, location and trade. World Economy, 21(6), 733-756. http://dx.doi.org/10.1111/1467-9701.00161

Markusen, J. R., \& Venables, A. J. (1998). Multinational firms and the new trade theory. Journal of International Economics, 46(2), 183-203. http:// dx.doi.org/10.1016/S0022-1996(97)00052-4

Merlevede, B. (2000). Growth in transition economies. A review of the literature. LICOS Discussion Paper, 9300. Available at http://www. econ.kuleuven.be/licos/publications/dp/dp93.PDF

North, D. C. (1991). Institutions. The Journal of Economic Perspectives, 5(1), 97-112. http://dx.doi.org/10.1257/jep.5.1.97

North, D. C. (2005). Understanding the process of economic change. New Jersey: Princeton University Press.

Oxley, J. E. (1999). Institutional environment and the mechanism of governance: The impact of intellectual property protection on the structure of inter-firm alliances. Journal of Economic Behavior and Organization, 38(3), 283-309. http://dx.doi.org/10.1016/S0167-2681(99)00011-6

Pournarakis, M., \& Varsakelis, N. (2004). Institutions, internationalization and FDI: The case of economies in transition. Transnational Corporation, 13(2), 77-94. Available at http://unctad.org/en/docs/iteiit 20045a5_en.pdf

Prüfer, P., \& Tondl, G. (2008). The FDI-growth nexus in Latin America: The role of source countries and local conditions. Tilburg University Discussion Paper, 61. Available at http://arno.uvt.nl/show.cgi?fid=80094

Rodrik, D. (2004). Globalization and growth looking in the wrong places. Journal of Policy Modeling, 26(4), 513-517. http://dx.doi.org/10. 1016/S0161-8938(04)00053-5

Rodrik, D., Subramanian, A., \& Trebbi, F. (2004). Institutions rule: The primacy of institutions over geography and integration in economic development. Journal of Economic Growth, 9(2), 131-165. http:// dx.doi.org/10.1023/B:JOEG.0000031425.72248.85

Roodman, D. (2009). How to do xtabond2: An introduction to difference and system GMM in Stata. Stata Journal, 9(1), 86-136. http://dx. doi.org/10.2139/ssrn. 982943

Schmieding, H. (1993). From plan to market: On the nature on the transformation crisis. Weltwirstschaftlishes Archiv, 129(2), 216-253. http:// dx.doi.org/10.1007/BF02707696

Sobel, A. C. (2002). State institutions, risk, and lending in global capital markets. International Business Review, 11(6), 725-752. http://dx. doi.org/10.1016/S0969-5931(02)00047-1 
DRUŠ. ISTRAŽ. ZAGREB GOD. 22 (2013), BR. 2, STR. 215-235

KERSAN-ŠKABIĆ, I.: INSTITUTIONAL...
Stiglitz, J. (1999). Whither reform? Ten years of transition. Keynote address at the Annual Bank Conference on Development Economics, World Bank, Washington. Available at http://siteresources.worldbank.org The Heritage Foundation (2012). The Index of Economic Freedom. Available at http://www.heritage.org/index

Transparency International (2012). Corruption Perception Index. Available at http://www.transparency.org/research/cpi/overview

Vaknin, S. (2011). Why the Constant Failure to Attract FDI to Macedonia. Conference "Twenty Years of Macedonian Independence: Economic, political and policy developments", CPRM. Available at http://ia700600.us.archive. org/3/items/WhyTheConstantFailureToAttractFdiToMacedonia/makf dilecturenotes.pdf

Walsh, J., \& Yu, J. (2010). Determinants of foreign direct investment: A sectoral and institutional approach. IMF Working Paper, 187. Available at http://www.imf.org

WEF (2012). Global Competitiveness Report. Available at http://www. weforum.org/issues/global-competitiveness

WIIW (2012). Handbook of Statistics, Central, East and Southeast Europe. Vienna: The Vienna Institute for International Economic Studies.

Williamson, O. E. (2000). The new institutional economics: Taking stock, looking ahead. Journal of Economic Literature, 38(3), 595-613. http:// dx.doi.org/10.1257/jel.38.3.595

World Bank (2012). The Worldwide Governance Indicators (WGI) project. Available at http://info.worldbank.org/governance/wgi

Zeghni, S., \& Fabry, N. (2006). How former communist countries of Europe may attract inward foreign direct investment? A matter of institutions. Communist and Post Communist Studies, 39(2), 201-219. http:// dx.doi.org/10.1016/j.postcomstud.2006.03.006

Zhang, K. H. (2001). Does foreign direct investment promote economic growth? Evidence from East Asia and Latin America. Contemporary Economic Policy, 19(2), 175-185. http://dx.doi.org/10.1093/cep/19.2.175

\section{Institucionalni razvoi kao odrednica atraktivnosti privlačenja inozemnih izravnih ulaganja (FDI) u Jugoistočnoj Europi}

Ines KERSAN-ŠKABIĆ

Sveučilište Jurja Dobrile u Puli, Pula

Cilj rada jest istražiti institucionalno okruženje $u$ zemljama Jugoistočne Europe (Albanija, Bosna i Hercegovina, Bugarska, Hrvatska, Makedonija, Crna Gora, Rumunjska i Srbija) i njegovo značenje $u$ atraktivnosti zemalja regije za privlačenje FDI-a. Izrađeno je nekoliko regresijskih modela kako bi odredili važnost odabranih lokacijskih determinanti. Modeli uključuju institucionalne varijable o napretku u procesu tranzicije, efikasnosti vlade, vladavini prava, 
DRUŠ. ISTRAŽ. ZAGREB GOD. 22 (2013), BR. 2 STR. 215-235

KERSAN-ŠKABIĆ, I.: INSTITUTIONAL... korumpiranosti, ali i varijable o ekonomskim obiliežjima SEE regije, kao što su BDP po stanovniku, stopa rasta, inflacija i plaće. Rezultati analize panel-podataka upućuju na značenje ekonomskih odrednica (BDP p. c. i inflacije) u privlačenju priljeva FDI-a, dok su među institucionalnim varijablama samo razina korumpiranosti, privatizacija velikih poduzeća, razvoi vanjskotrgovinskoga i deviznoga sustava te ukupne infrastrukturne reforme, što osjetno utječe na priljeve FDI-a. Sloboda (zaštita) imovinskih prava i privatizacija malih poduzeća nisu značajne varijable. Nakon uklanjanja multikolinearnosti možemo zaključiti da BDP p. c., inflacija, trgovinski i devizni sustav, korumpiranost i ukupne infrastrukturne reforme ostaju značajne varijable u objašnjenju ekonomskih i institucionalnih odrednica priljeva FDI-a.

Ključne riječi: institucionalni razvoj, FDI (inozemna izravna ulaganja), SEE regija 